\title{
PKM bagi Industri Rumah Tangga di Desa Trimulyo, Kecamatan Jetis, Kabupaten Bantul
}

\author{
Iva Mindhayani ${ }^{1}$, Siti Lestariningsih ${ }^{2}$, Susianti $^{3}$ \\ 1,2 Dosen Universitas Widya Mataram, nDalem Mangkubumen KT.III/237 Yogyakarta \\ ${ }^{3}$ Dosen Akademi Manajemen Administrasi Dharmala, J1. Letjen Suprapto No. 70, Yogyakarta \\ e-mail: ivamindayani@gmail.com
}

\begin{abstract}
Home industry can be a solution in the household economy. Rondiyah's home industry as a partner with the name "Mr. Slamet's Chips" in Trimulyo Village has several problems. Especially the quality of products that have not been stable, packaging is only perfunctory without labeling and there is no recording/accounting of business finances. Businesses that are run by partners have not been well and professionally managed. Through the Community Partnership Program (PKM), the service team offers solutions to problems experienced by partners by providing assistance. The main activities of the assistance are carried out in a way; 1) provide training on the process of making tempe chips with controlled production methods, 2) entrepreneurship training by packaging branding, 3) financial management training by making simple financial accounting. The results achieved in community service activities are the quality and quality of the product increases, packaging becomes more attractive by labeling the packaging, knowledge and ability of simple financial accounting increases.
\end{abstract}

Keywords: PKM, home industry, production, branding, financial accounting

\begin{abstract}
Abstrak
Industri rumah tangga bisa menjadi solusi perekonomian dalam rumah tangga. Industri rumah tangga milik ibu Rondiyah selaku mitra dengan nama "keripik Pak Slamet" di Desa Trimulyo mengalami beberapa permasalahan. Terutama mutu produk yang belum stabil, pengemasan yang hanya ala kadarnya tanpa pemberian label serta tidak adanya pencatatan/pembukuan keuangan usaha. Usaha yang dijalankan oleh mitra belum dikelola dengan baik dan profesional. Melalui Program Kemitraan Masyarakat (PKM) ini tim pengabdi menawarkan solusi terhadap permasalahan yang dialami oleh mitra dengan melakukan pendampingan. Kegiatan pokok pendampingan dilakukan dengan cara; 1) memberikan pelatihan tentang proses pembuatan keripik tempe dengan metode produksi terkontrol, 2) pelatihan kewirausahaan dengan melakukan branding kemasan, 3) pelatihan manajemen keuangan dengan membuat pembukuan keuangan sederhana. Kegiatan pendampingan ini bertujuan agar terjadi transfer ilmu pengetahuan dan teknologi (IPTEKS) dari perguruan tinggi langsung kepada mitra untuk membantu menyelesaikan permasalahan yang ada. Hasil yang dicapai dalam kegiatan pengabdian masyarakat adalah kualitas dan mutu produk meningkat, kemasan menjadi lebih menarik dengan memberikan label pada kemasan, pengetahuan dan kemampuan pembukuan keuangan sederhana meningkat.
\end{abstract}

Kata Kunci: PKM, industri rumah tangga, produksi, branding, pembukuan keuangan 


\section{PENDAHULUAN}

Industri rumah tangga merupakan industri yang jumlah pekerjanya terdiri dari 1-4 orang pekerja (Deni, M., 2016). Pekerja yang terlibat dalam produksi merupakan anggota keluarga atau tetangga dekat. Selain itu industri rumah tangga mempunyai ciri proses teknologi sederhana dan penggunaan peralatan yang relatif sederhana. Industri rumah tangga bisa menjadi penopang perekonomian dalam rumah tangga. Pelaku industri rumah tangga pada umumnya dijalankan oleh ibu-ibu rumah tangga, karena memiliki waktu yang lebih fleksibel dan disesuaikan dengan kondisi para pelaku usaha. Mildan (2016) menyatakan bahwa industri rumah tangga mampu menjadi solusi brilian di tengah kondisi perekonomian yang tidak menentu. Industri rumah tangga bagian dari jenis industri yang ada. Restanto (TT) menyatakan bahwa Industri adalah kegiatan yang dilakukan oleh manusia yang mengolah bahan mentah menjadi barang jadi atau barang setengah jadi untuk menghasilkan barang yang mempunyai nilai tinggi. Menurut Saleh dalam Restanto (TT) alasan kuat yang mendasari resistensi keberadaan industri kecil yaitu, pertama: sebagian populasi industri kecil berada di pedesaaan dikaitkan dengan tenaga kerja yang semakin meningkat serta luas tanah garapan pertanian yang relatif berkurang, sehingga industri kecil merupakan alternatif jalan keluarnya. Kedua beberapa jenis kegiatan industri kecil banyak menggunakan bahan baku dari sumber di lingkungan terdekat, di samping tingkat upah yang murah, biaya produksi juga merupakan aspek pendukung yang kuat.

Dalam usaha pengembangannya industri rumah tangga masih banyak menghadapi kendala. Untuk itu supaya industri rumah tangga mampu bersaing pada era globalisasi, maka diperlukan pembinaan dan pendampingan yang berkelanjutan, serta pengelolaan yang baik dan profesional. Dengan begitu, diharapkan industri rumah tangga menjadi semakin berkembang dan tangguh.

Permasalahannya industri rumah tangga banyak yang belum dikelola secara baik dan profesional. Seperti yang dialami oleh mitra PKM yang berlokasi di dusun Ponggok Desa Trimulyo, Jetis, Bantul. Mitra yang memiliki usaha olahan makanan yaitu keripik tempe dengan nama "Keripik Pak Slamet" yang dikelola oleh Ibu Rondiyah masih menjalankan usahanya hanya sekedar bisa jalan tanpa adanya perencanaan yang matang. Permasalahan itu tidak hanya dialami oleh mitra tapi juga beberapa industri rumah tangga yang berada di dusun Ponggok desa Trimulyo Jetis Bantul.

Permasalahan yang dialami oleh mitra yaitu keterbatasan pengetahuan dalam proses produksi seperti ketebalan keripik tempe yang tidak seragam, rasa yang tidak stabil, pengemasan produk yang ala kadarnya tanpa pemberian label, pengembangan produk, sistem pemasaran dan operasional menjadikan produk-produk yang ada belum mencapai kondisi optimal untuk peningkatan pangsa pasar. Di sisi lain, manajemen keuangan belum dikelola dengan baik hal tersebut terlihat dari pencatatan keuangan belum dilakukan secara baik. Hal ini mengakibatkan tidak adanya pemisahan antara harta pribadi dengan harta usaha yang menyebabkan pelaku usaha tidak dapat mengetahui arus keuangan usaha secara pasti. Kondisi inilah yang dialami oleh Ibu Rondiyah selaku mitra dan sebagian besar pelaku industri rumah tangga di daerah kegiatan PKM ini. Hal ini menjadi kendala dalam pengembangan 
usaha pada industri rumah tangga di Desa Trimulyo, Jetis, Bantul.

Berdasarkan permasalahan tersebut, maka tim pengabdi ingin melakukan transfer ilmu pengetahuan dan teknologi (IPTEKS) kepada mitra untuk membantu menyelesaikan permasalahan yang ada.

\section{METODE PELAKSANAAN}

Pelaksanaan PKM dilakukan di Ponggok I, Desa Trimulyo, Kecamatan Jetis, Kabupaten Bantul, D.I Yogyakarta. Dalam pelaksanaan Kegiatan PKM ini dengan memberikan bantuan alat, penyuluhan, pelatihan dan pendampingan. Bentuk kegiatan utama yang dilaksanakan dalam PKM ini meliputi tiga tahapan kegiatan (Maulani, dkk., 2016), yaitu pertama, tahap awal meliputi kegiatan survey dan wawancara langsung dengan pihakpihak terkait, salah satunya dengan Ibu Rondiyah sebagai pelaku usaha. Tim PKM melakukan pembuatan materi pelatihan branding, produksi dan pembukuan keuangan sederhana

Kedua, tahap pelaksanaan yang meliputi pelaksanaan pelatihan branding, produksi dan pencatatan/pembukuan keuangan sederhana. Metode dalam penyampaian materi pembukuan keuangan sederhana berdasarkan pada acuan teori sistem akuntansi yang berhubungan dengan pencatatan keuangan yang berlaku secara umum dan dibentuk sebagai alat pencatatan transaksi keuangan pada sebuah UKM (Wardi, 2014).

Ketiga, merupakan tahap terakhir dalam kegiatan PKM yaitu meliputi kegiatan monitoring dan pendampingan dalam industri rumah tangga Ibu Rondiyah.

\section{HASIL DAN PEMBAHASAN}

Pengabdian kepada Masyarakat merupakan program yang berupaya untuk melakukan edukasi kepada masyarakat yang berupa pengenalan dan penerapan inovasi teknologi dalam rangka meningkatkan pengetahuan, kecerdasan, kesejahteraan dan kemakmuran masyarakat. Ranjith dan Banda dalam Putra, dkk (2018) mengemukakan bahwa kualitas entrepreneur merupakan suatu variabel yang sangat penting dalam memperoleh sukses bagi para UMKM.

Berdasarkan rencana yang sudah ditentukan, kegiatan PKM ini diawali dengan survei lokasi dan usaha Industri Rumah Tangga, serta kegiatan administratif yang meliputi perijinan, dan undangan pelatihan bagi peserta yang tergabung dalam paguyupan "Paguhati" dan juga merupakan warga Desa Trimulyo, Kecamatan Jetis, Kabupaten Bantul.

Kegiatan selanjutnya, dilaksanakan pelatihan yang diawali dengan penyerahan bantuan alat produksi berupa alat pemotong untuk pembuatan keripik tempe, penggorengan, spinner dan alat las plastik. pada tanggal 13 Juli 2019 di Rumah Bu Rondiyah, Ponggok I, Desa Trimulyo, Jetis, Bantul.

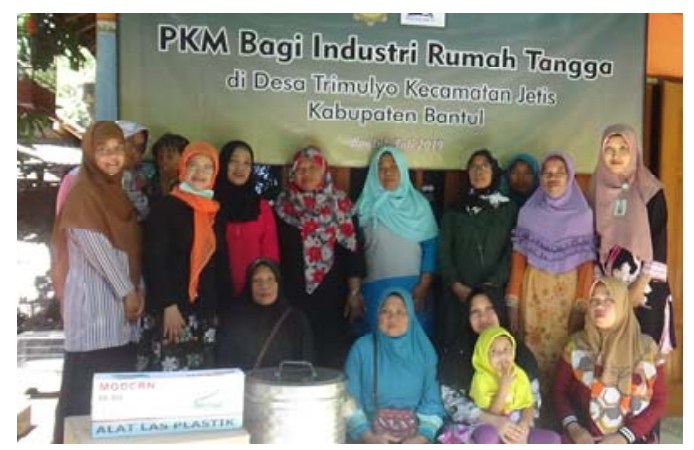

Gambar 1. Penyerahan Bantuan Alat Produksi

Kegiatan pelatihan dibagi menjadi tiga bagian materi, yaitu branding kemasan, produksi, dan manajemen keuangan. Adapun hasil pembahasan materi kegiatan pelatihan dalam PKM ini dapat dijelaskan berikut ini:

1. Pelatihan branding kemasan

Branding kemasan merupakan salah satu strategi pemasaran dalam pengembangan usaha supaya lebih dikenal oleh masyarakat luas. 
Pelatihan ini bertujuan agar mitra mempunyai pengetahuan tentang inovasi kemasan serta branding agar lebih menarik dan mudah diingat serta pencantuman legalitas hasil produk dengan PIRT. Hal ini akan menambah keyakinan konsumen terhadap produk yang dihasilkan.

Branding kemasan dilakukan dengan memberikan label pada kemasan serta kemasan yang menarik menjadi bagian dari bauran pemasaran. Tim dan mitra membuat desain label berdasarkan hasil kesepakatan bersama. Selanjutnya label dicetak sebagai stiker sehingga mudah dalam penggunaannya. Produk yang telah dikemas dan diberikan label memberikan dampak yang baik. Berdasarkan informasi yang diberikan oleh mitra didapatkan keterangan setelah produk dikemas dengan rapi dan diberikan label dipromosikan via whats ap ternyata mendapat respon positif dan beberapa langsung memesannya. Pemberian label dan kemasan yang menarik bertujuan agar produk yang ditawarkan ke pasar mendapat perhatian, dibeli, dipergunakan atau dikonsumsi dan yang dapat memuaskan keinginan atau kebutuhan (Daryanto, 2012). Menurut Dewi (2017) dalam penelitiannya menyatakan bahwa kemasan memiliki pengaruh positif dan signifikan terhadap minat beli.

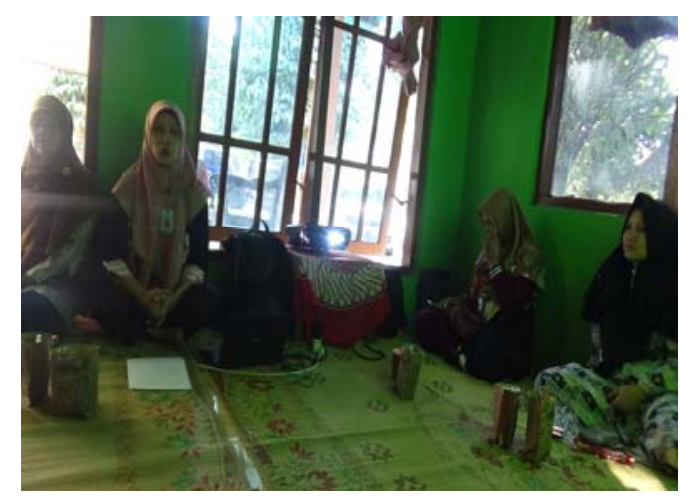

Gambar 2. Penjelasan Materi Pelatihan Branding kemasan

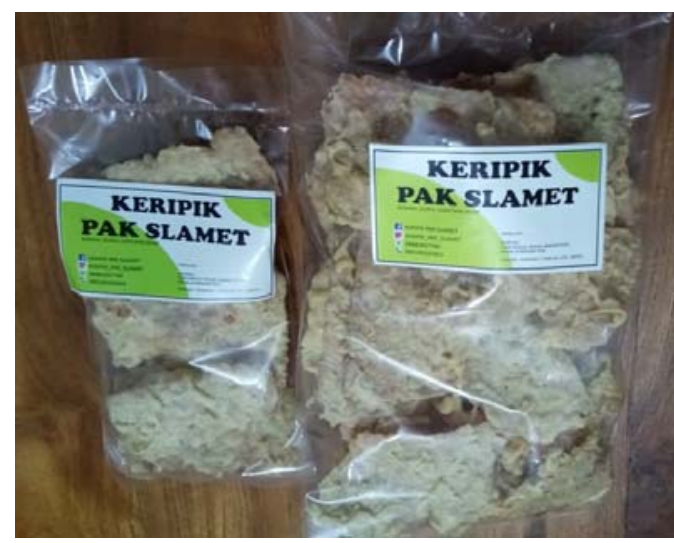

Gambar 3. Praktek Branding Kemasan

2. Pelatihan produksi terkontrol

Pelatihan ini bertujuan untuk memberikan edukasi dalam menjaga kualitas dan mutu produk. Pada pelatihan produksi terkontrol disampaikan materi tentang pentingnya konsistensi dalam proses produksi. sehingga kualitas dan mutu produk meningkat serta memiliki keunggulan. Menurut Winarto (2011) keunggulan produk dibandingkan dengan produk sejenis lainnya bisa menjadi daya tarik utama. Di samping itu, dalam pelatihan disampaikan bahwa semua tahapan dalam proses produksi seperti dalam proses pembuatan adonan keripik semua komposisi bahan harus pas sesuai takaran, ketebalan keripik tempe seragam. Mitra juga diberikan pelatihan tentang cara penggunaan peralatan pendukung produksi yang telah diberikan.

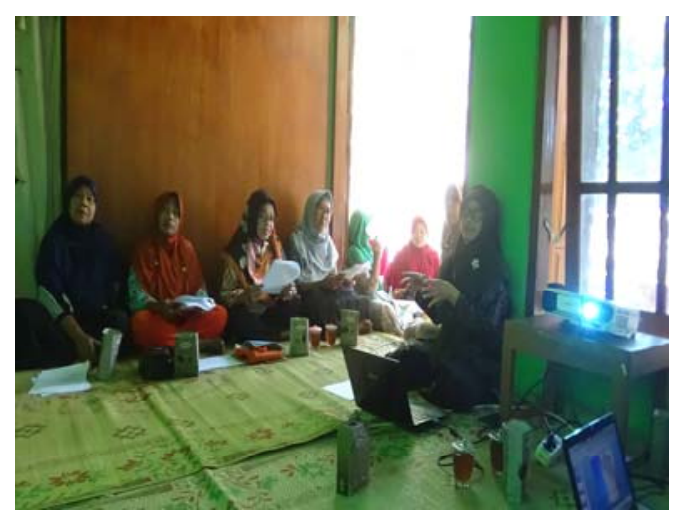

Gambar 4. Penjelasan Materi Pelatihan Produksi 


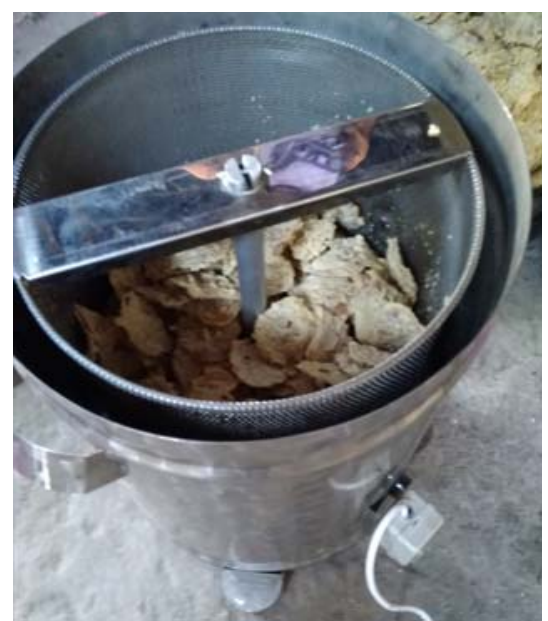

Gambar 5. Praktek Produksi

3. Pelatihan pembukuan keuangan sederhana bertujuan untuk memberikan edukasi dalam meningkatkan pengetahuan, pemahaman, dan keterampilan pelaku usaha Industri Rumah Tangga, sehingga mereka mempunyai kemampuan yang cukup baik dalam memisahkan antara keuangan pribadi. Selanjutnya, para pelaku usaha ini bisa mengetahui perkembangan usahanya melalui pencatatan/pembukuan yang dilakukan dengan baik (Maulani, dkk., 2016).

Mengacu pendapat Nurlaela (2014) maka materi pembukuan keuangan yang disampaikan adalah berkaitan dengan tujuan pelaporan keuangan yang dicanangkan dalam APB No. 4 untuk tujuan dasar akuntansi keuangan dan laporan keuangan dalam memberikan informasi tentang keuangan perusahaan yang berguna untuk membuat keputusan ekonomi, maka materi yang disampaikan dalam pelatihan pembukuan keuangan sederhana ini, meliputi:

a. Materi pembukuan keuangan sederhana secara umum. Dalam materi ini, penjelasan yang disampaikan tentang pentingnya pencatatan/pembukuan

keuangan dalam usaha dan pentingnya adanya pemisahan antara keuangan pribadi dengan keuangan usaha dengan baik dalam menjalankan usaha.

b. Jenis dan komponen laporan keuangan (Sugiri \& Bogat A.R, 2015), yaitu:

- Laporan arus kas yang digunakan untuk menjelaskan dan menunjukkan semua aspek yang berkaitan dengan kegiatan usaha, baik yang berpengaruh langsung atau tidak langsung terhadap kas, yang meliputi kas masuk (pemasukan) dan kas keluar (pengeluaran) dan sumbersumbernya dalam satu periode.

- Laporan laba rugi yang digunakan untuk mengetahui hasil usaha dalam periode tertentu (kondisi laba atau menderita kerugian), yang terdiri dari jumlah pendapatan dan sumber pendapatan serta jumlah biaya dan jenis-jenis biaya.

- Laporan perubahan modal yang berisi jumlah dan jenis modal yang dimiliki pada saat ini dan menjelaskan perubahan modal dan sebabsebab terjadi perubahan modal dalam usaha.

- Neraca menunjukkan posisi keuangan pada periode tertentu yang berisi informasi tentang Aktiva (harta) dan Pasiva (kewajiban dan ekuitas) dan komponenkomponennya.

- Penerapan materi: praktek pembukuan keuangan sederhana berdasarkan usaha para peserta pelatihan. 


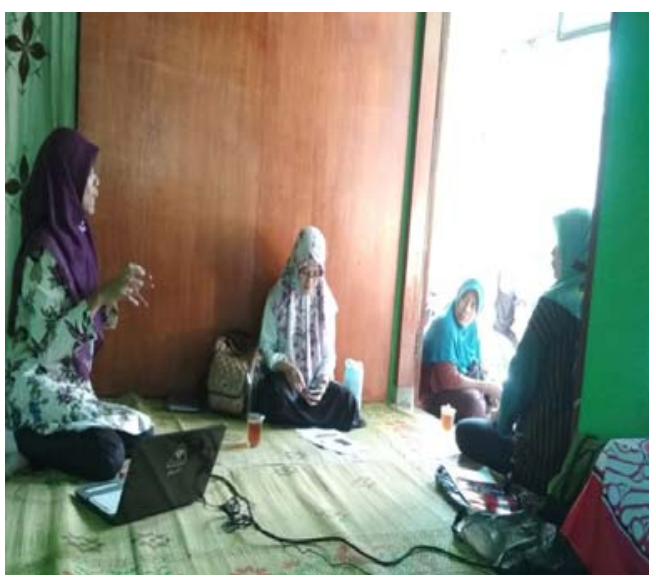

Gambar 6. Penjelasan Materi Pelatihan Pembukuan Keuangan Sederhana

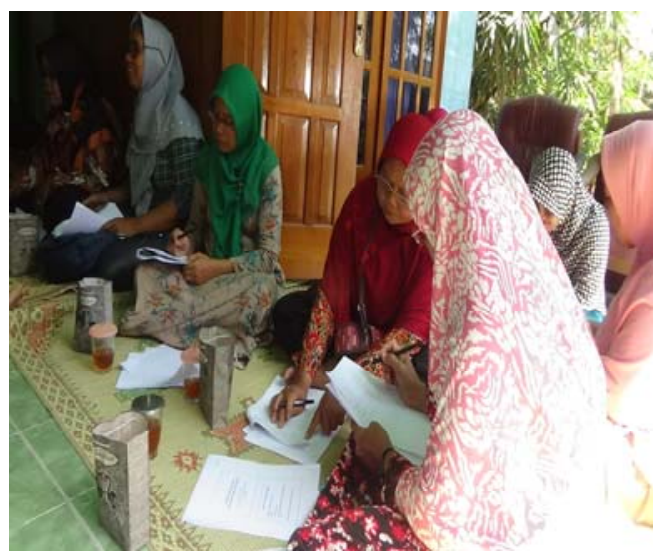

Gambar 7. Praktek Pembukuan

Keuangan sederhana

Berdasarkan pelatihan yang telah diberikan, pengetahuan, pemahaman dapat diserap peserta. Hal tersebut didukung oleh adanya sesi tanya jawab dan diskusi dalam kegiatan pelatihan ini menyebabkan terjadi komunikasi dua arah cukup baik sehingga menambah pengetahuan, pemahaman dan meningkatkan kemampuan/ keterampilan bagi pelaku usaha dalam branding kemasan, produksi dan pembukuan keuangan sederhana. Sesi tanya jawab dan diskusi ini berlangsung secara terarah dan tertib sesuai dengan materi yang disampaikan. Peserta cukup antusias berperan aktif dalam melakukan tanya jawab dan diskusi terkait dengan pertanyaan permasalahan yang mereka hadapi dalam menjalankan usaha masing-masing.
Hasil dari pelatihan branding kemasan, mitra mulai memberikan label pada kemasan dan pengemasan lebih rapi dibanding sebelumnya sehingga produk keripik yang dihasilkan mitra semakin dikenal oleh masyarakat luas. Hasil pelatihan produksi terkontrol menjadikan keripik yang dihasilkan memiliki rasa yang stabil, minyak yang menempel pada keripik berkurang. Sedangkan hasil pelatihan pembukuan adalah mitra mulai melakukan pencatatan keuangan meskipun masih sangat sederhana hanya berupa pemasukan dan pengeluaran.

Tahap terakhir dalam kegiatan PKM ini adalah kegiatan monitoring, pendampingan dan evaluasi kepada mitra. Karena dalam hal ini mitra masih membutuhkan masukan-masukan dan bahan evaluasi untuk meningkatkan usahanya. Selain itu, tim juga melakukan monitoring agar mitra konsisten terhadap apa yang telah didapat pada kegiatan pelatihan.

\section{PENUTUP}

\section{Kesimpulan}

Kegiatan pengabdian masyarakat di Dusun Ponggok, Desa Trimulyo, Kecamatan Jetis, Kabupaten Bantul telah mampu meningkatkan kualitas produk keripik tempe.Keripik bayam yang diproduksi oleh mitra dan kemasaan yang sudah berlabel membuat lebih menarik. Selain itu, pengetahuan manajemen keuangan mitra dalam hal pembukuan keuangan sederhana meningkat, mitra mulai melakukan pencatatan keuangan meskipun masih berupa pencatatan pengeluaran dan pemasukan secara sederhana, mitra mengetahui pemisahan keuangan pribadi dan keuangan usaha.

\section{Saran}

1. Penyuluhan, pelatihan dan pendampingan tentang pentingnya melakukan strategi pemasaran, pencatatan keuangan kepada pelaku usaha industri rumah tangga di Ponggok I, Desa Trimulyo, Jetis, 
Bantul, perlu dilakukan secara berkelanjutan.

2. Perlu adanya perhatian, peran serta yang lebih baik dan sinergi pemerintah daerah dan pihak-pihak terkait dalam memberikan pembinaan bagi para pelaku usaha industri rumah tangga dalam rangka meningkatkan pemberdayaan masyarakat.

\section{UCAPAN TERIMA KASIH}

Ucapan terimakasih terutama kami haturkan kepada Kemenristek Dikti yang telah memberikan dana hibah pada kegiatan Pengabdian kepada Masyarakat pada Progam Kemitraan Masyarakat tahun 2019 dengan Nomor Kontrak: $\quad$ 04/PKM/LPPMUWM/VI/2019. Ucapan terimakasih juga disampaikan kepada Ibu Rondiyah selaku mitra serta ibu-ibu kelompok Paguhati, Ponggok, Desa Trimulyo, Jetis Bantul selaku peserta pelatihan.

\section{DAFTAR PUSTAKA}

Daryanto, 2012. Pendidikan Kewirausahaan. Yogyakarta: Gava Media.

Dewi, R.C., 2017. Pengaruh Kemasan, Harga dan Kualitas Terhadap Minat Beli. (Skripsi), Program Studi Manajemen Universitas Sanata Dharma Yogyakarta.

Hestanto, TT. Pengertian Istilah Industri Kecil dan Kerajinan Rumah Tangga. Bisa diakses di https://www.hestanto.web.id/peng ertian-istilah-industri-kecil-dankerajinan-rumah-tangga/

Maulani, Terra Saptina., Fia Dialysa, dan Kannya PP. 2016. Pelatihan Pembukuan Keuangan Sederhana dan Motivasi Kewirausahaan pada Kelompok Usaha Makanan RW
02 Kelurahan Neglasari Kecamatan Cibeunying Kaler Bandung. Jurnal Dharma Bhakti STIE Ekuitas 01(01): 32-37.

Mildan, D. 2016. Industri Rumah Tangga: Sebuah Solusi Brilian. Bisa diakses di https://www.kompasiana.com/den imildan/571704fb507a612f05033f 3e/industri-rumah-tangga-sebuahsolusi-brilian.

Nurlaela, Siti. 2015. Kemampuan Menyusun Laporan Keuangan usaha Kecil Menengah Pengaruhnya Terhadap Kinerja UKM Kerajinan Gitar di Kabupaten Sukoharjo. Jurnal Paradigma, 12 (02):50-59.

Putra, A.P., Purwanto., Widati, S. 2018. Pelatihan Strategi Branding dan Packaging Pada Usaha Home Industri Pembuatan "Karak" di Desa Dukuh Mojolaban Sukoharjo. Prosiding Seminar Nasional Tahun 2018 Publikasi Hasil Penelitian san Pengabdian kepada Masyarakat. Universitas Veteran Bangun Sukoharjo: 6569.

Sugiri, Slamet, \& Bogat Agus Riyono. 2015. Akuntansi Pengantar 1, Edisi ke-9, Yogyakarta: UPP STIM YKPN.

Wardi, Jeni. 2014. Penerapan Pencatatan Keuangan pada Usaha Kecil dan Menengah. Jurnal Pekbis, 6 (3):197-207.

Winarto, H. 2011. Strategi Pemasaran. Majalah Ilmiah Ekonomika 14(3): 124-128. Agustus 2011. 